\title{
PERAMALAN DAN PENENTUAN TARGET PRODUKSI KEDELAI NASIONAL
}

\author{
Eko Ruddy Cahyadi ${ }^{1 *}$, Nurul Hidayati ${ }^{1}$ \\ ${ }^{1}$ Departemen Manajemen, Fakultas Ekonomi dan Manajemen IPB University \\ *Email: ekocahyadi@apps.ipb.ac.id
}

\section{RINGKASAN}

Kedelai merupakan salah satu bahan pangan yang banyak dikonsumsi masyarakat Indonesia dalam bentuk produk olahan seperti tempe, tahu, dan kecap. Permintaan kedelai mentah sebagai bahan baku cenderung meningkat melampaui kapasitas produksi dalam negeri. Tercatat hanya sekitar $65 \%$ produksi lokal untuk memenuhi pasar kedelai domestik dan selebihnya berasal dari impor. Oleh karena itu, kebijakan dan program yang tepat untuk peningkatan produksi lokal sangat dibutuhkan. Hal pertama yang perlu dilakukan adalah menentukan target produksi kedelai yang akan dicapai. Target ini akan menentukan alokasi sumberdaya dan program yang sesuai. Dalam risalah ini dilakukan kajian penentuan target yang akuntabel dan realiastis melalui pendekatan peramalan kuantitatif. Hasil kajian menunjukkan bahwa metode peramalan weighted moving average untuk data produksi tahunan dan metode Holt's Winter (Multiplicative) untuk data produksi musiman adalah model peramalan terbaik dengan tingkat kesalahan terkecil. Kedua metode ini dapat diadopsi oleh Kementerian Pertanian dalam menentukan target produksi kedelai. Kisaran target produksi kedelai yang direkomendasikan untuk tahun 2019 adalah 971,489.45 \pm 132,732.33 ton.

Kata kunci: Holt's Winter, kedelai, peramalan, target, weighted moving average.

\section{PERNYATAAN KUNCI}

Kebutuhan konsumsi kedelai yang terus meningkat belum mampu dipenuhi oleh produksi domestik yang mengalami fluktuasi dalam lima tahun terakhir. Kementerian Pertanian perlu menentukan target produksi yang tepat sebagai dasar untuk membuat kebijakan dan program peningkatan produksi kedelai dalam negeri. Penentuan target memerlukan metode yang handal, realistis, dan akuntabel. Salah satu pendekatan yang dapat digunakan untuk menentukan target adalah pendekatan peramalan kuantitatif. Meskipun target berbeda dengan peramalan namun penetuan target yang realistis dan akuntabel perlu mempertimbangkan peramalan yang bersifat faktual obyektif dengan memasukan tingkat optimisme pembuat 
kebijakan sesuai dengan visi dan misi organisasi. Metode peramalan kuantitatif yang digunakan dalam kajian ini didasarkan pada data deret waktu (time series) produksi kedelai dari tahun 20002018. Metode peramalan terbaik dipilih berdasarkan tingkat kesalahan estimasi (error) yang terkecil.

\section{REKOMENDASI}

Kajian risalah kebijakan ini merekomendasikan metode peramalan weighted moving average untuk memprediksi data produksi tahunan dan metode Holt's Winter (Multiplicative) untuk memprediksi produksi musiman kedelai nasional. Kedua metode ini adalah metode dengan tingkat error terkecil baik dari evaluasi MAD, MSE, dan MAPE dibandingkan dengan metode kuantitatif lainnya. Kisaran target produksi kedelai pada tahun 2019 yang dapat ditentukan adalah untuk metode weighted moving average berkisar $971,489.45 \pm 132,732.33$ ton kedelai. Sementara metode Holt's Winter (Multiplicative) pada tahun 2019 untuk periode Januari-April $61,133.67 \pm$ 205,386.97 ton; Mei-Agustus 61,133.67 \pm 240,794.38 ton; dan September Desember $61,133.67 \pm 281,164.55$ ton. Metode ini dapat diadopsi oleh Kementerian Pertanian dalam menentukan target produksi kedelai yang akan dijadikan sebagai dasar dalam membuat kebiajkan dan program kegiatan pertanian untuk meningkatkan produksi kedelai dalam negeri dan mengurangi impor kedelai.

\section{PENDAHULUAN}

Kedelai merupakan komoditas pangan dengan kandungan protein nabati tinggi dan telah digunakan sebagai bahan baku produk olahan seperti susu kedelai, tempe, tahu, kecap, dan berbagai makanan ringan lainnya (Krisnawati, 2017). Di Indonesia kedelai termasuk tanaman strategis ke tiga setelah padi dan jagung (Aldillah, 2014) yang memiliki nilai ekonomi tinggi. Kesadaran akan kandungan gizi yang melimpah sebagaimana disajikan pada Tabel 1 dan manfaatnya sebagai pangan fungsional yang baik bagi kesehatan menyebabkan konsumsi makanan olahan kedelai meningkat setiap tahun.

Tabel 1 Kandungan gizi kedelai

\begin{tabular}{ll}
\hline Komponen & $\begin{array}{l}\text { Kandungan dalam } \\
\text { 100g Ekstrak jernih } \\
\text { Kedelai }\end{array}$ \\
\hline Energi & $145 \mathrm{kj}$ (36 kkal) \\
Protein & $3.2 \mathrm{~g}$ \\
Karbohidrat & $3.0 \mathrm{~g}$ \\
Serat Kasar & $0.1 \mathrm{~g}$ \\
Lemak & $1.5 \mathrm{~g}$ \\
Asam lemak tidak & Tinggi \\
jenuh ganda (PUFA) & \\
Asam lemak jenuh & Rendah \\
Kolesterol & $0 \mathrm{mg}$ \\
Vitamin A & $41.2 \mathrm{IU}$ \\
Vitamin C & $0 \mathrm{mg}$ \\
Thiamin (B1) & $0.05 \mathrm{mg}$ \\
Riboflavin (B2) & $0.03 \mathrm{mg}$ \\
Sodium & $21.6 \mathrm{mg}$ \\
\hline
\end{tabular}




\begin{tabular}{ll}
\hline Potassium & $133.4 \mathrm{mg}$ \\
Kalsium & $21.6 \mathrm{mg}$ \\
Besi & $1.2 \mathrm{mg}$ \\
\hline \multicolumn{2}{c}{ Pangan fungsional berperan sebagai }
\end{tabular}
pemelihara kesehatan dan mencegah berbagai penyakit. Pangan fungsional adalah pangan yang secara alamiah maupun melalui proses mengandung satu atau lebih senyawa yang mempunyai fungsi fisiologis tertentu yang bermanfaat bagi kesehatan (BPOM, 2005). Terdapat tiga persyaratan pangan fungsional, yaitu (1) produk berupa bahan pangan (bukan kapsul, tablet atau bubuk) dan berasal dari bahan alami, (2) layak dikonsumsi sebagai bagian dari menu sehari-hari, dan (3) mempunyai fungsi pada waktu dicerna, seperti memperkuat pertahanan tubuh, mencegah penyakit tertentu, membantu memulihkan kondisi tubuh setelah sakit, menjaga kondisi fisik dan mental, dan memperlambat proses penuaan. Kedelai sebagai sumber pangan fungsional mengandung komponen penting yang berguna untuk kesehatan, termasuk vitamin (vitamin $\mathrm{A}, \mathrm{E}, \mathrm{K}$ dan beberapa jenis vitamin B) dan mineral ( $\mathrm{K}, \mathrm{Fe}, \mathrm{Zn}$ dan P). Lemak kedelai mengandung 15\% asam lemak jenuh dan sekitar 60\% lemak tidak jenuh yang berisi asam linolenat dan linoleat, keduanya diketahui membantu menyehatkan jantung dan mengurangi risiko terkena kanker.
Meningkatnya permintaan kedelai untuk bahan pangan dari tahun ke tahun didorong oleh peningkatan jumlah penduduk dan kesadaran akan pentingnya gaya hidup sehat. Pasokan kedelai di Indonesia terkadang tidak mampu memenuhi keseluruhan permintaan kedelai di pasar sehingga pemerintah melakukan impor kedelai untuk mencukupi kebutuhan tersebut. Hal ini digambarkan dengan adanya fakta bahwa pertumbuhan kebutuhan konsumsi kedelai melebihi pertumbuhan produksi dalam negeri, sehingga kekurangan kebutuhan ditutup dari kedelai impor (Aldillah, 2014). Produksi kedelai di dalam negeri hanya mampu memenuhi sekitar 65,61\% konsumsi domestik (FAO, 2013) sehingga sebesar $35 \%$ dipenuhi dari kedelai impor (Departemen Pertanian 2008).

\section{METODOLOGI}

Penelitian ini dilakukan menggunakan data produksi kedelai tahun 2000 - 2018 dari BPS dan tinjauan literatur yang relevan dengan kajian. Focus Group Discussion (FGD) dengan Biro Perencanaan Kementrian Pertanian juga dilakukan untuk mengkonfirmasi dan menginterpretasikan data.

Metode analisis data yakni dengan menggunakan metode peramalan kuantitatif. Metode peramalan kuantitatif 
yang digunakan adalah 4 metode dengan data tahunan yakni moving average, weighted moving average, exponential smoothing, dan Holt's Trend. Selanjutnya terdapat 2 metode dengan data musiman yakni Holt's Winter (Multiplicative), dan Holt's Winter (Additive). Penentuan target dapat ditentukan dengan menggunakan hasil peramalan dengan kisaran nilai tingkat kesalahan terkecil. Tingkat kesalahan tersebut diukur melalui empat indikator, yakni RMSE (Root mean square error), MAE (Mean Absolute Error), dan MAPE (Mean Absolute Prcentage Error). Model peramalan terbaik adalah metode yang menghasilkan nilai terkecil untuk ketiga indikator tersebut. Pengolahan data menggunakan perangkat lunak Microsoft Excel dengan add in Realstat dan solver. Kerangka pemikiran penelitian disajikan pada Gambar 1.

\section{Data historis tahunan: moving} average, weighted moving average, exponential smoothing, dan Holt's Trend

Data historis musiman: Holt's Winter (Multiplicative), dan Holt's Winter (Additive). Tidak kedelai saat ini
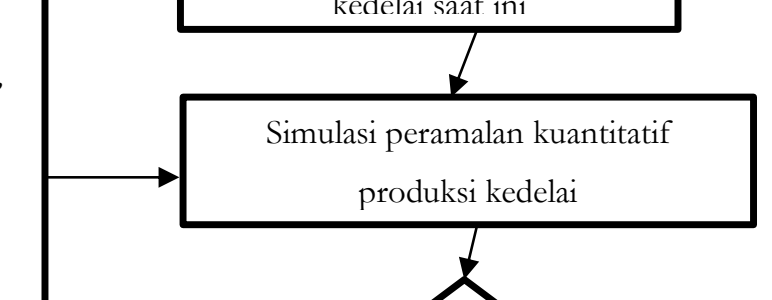
kisaran angka 500-1000 ton sebagaimana

disajikan pada Tabel 2.

Tabel 2 Produksi kedelai nasional tahunan (BPS 2019)

\begin{tabular}{rrrr}
\hline Tahun & Produksi nasional (ton) & \multicolumn{1}{l}{ Tahun } & Produksi nasional (ton) \\
\hline 2000 & $1,017,634.00$ & 2010 & $907,031.00$ \\
2001 & $826,932.00$ & 2011 & $851,286.00$ \\
2002 & $673,056.00$ & 2012 & $843,153.00$ \\
2003 & $671,600.00$ & 2013 & $779,992.00$ \\
2004 & $723,483.00$ & 2014 & $954,997.00$ \\
2005 & $808,353.00$ & 2015 & $963,183.00$ \\
2006 & $649,835.00$ & 2016 & $859,653.00$ \\
2007 & $586,018.00$ & 2017 & $538,728.00$ \\
2008 & $775,710.00$ & $2018 *$ & $982,598.00$ \\
2009 & $974,512.00$ & & \\
\hline
\end{tabular}

*angka sementara 
Tabel 3 Perkembangan luas panen, produktivitas, dan produksi musiman komoditi kedelai

\begin{tabular}{|c|c|c|c|c|c|c|c|c|c|c|c|}
\hline \multirow[t]{3}{*}{ Uaian } & \multirow[t]{3}{*}{2014} & \multirow[t]{3}{*}{2015} & \multirow[t]{3}{*}{2016} & \multirow[t]{3}{*}{2017} & \multirow[t]{3}{*}{$2018 *)$} & \multicolumn{6}{|c|}{ Perkembangan } \\
\hline & & & & & & \multicolumn{2}{|c|}{$2015-2016$} & \multicolumn{2}{|c|}{$2016-2017$} & \multicolumn{2}{|c|}{$2017-2018 *)$} \\
\hline & & & & & & Absolut & $\%$ & Absolut & $\%$ & Absolut & $\%$ \\
\hline \multicolumn{12}{|l|}{ KEDELAI } \\
\hline \multicolumn{12}{|l|}{ Luas Panen (ha) } \\
\hline 1. Januari-April & 169,291 & 144,130 & 193,359 & 92,294 & 198,941 & 49,229 & 34 & $-101,065$ & -52.27 & 106,647 & 115.55 \\
\hline 2. Mei-Agustus & 222,589 & 245,487 & 180,679 & 120,076 & 174,954 & $-64,808$ & -26 & $-60,603$ & -33.54 & 54,878 & 45.70 \\
\hline 3. September-Desember & 223,805 & 224,478 & 202,949 & 143,419 & 166,353 & $-21,529$ & -10 & $-59,530$ & -29.33 & 22,934 & 15.99 \\
\hline - Januari-Desember & 615,685 & 614,095 & 576,987 & 355,789 & 540,247 & $-37,108$ & -6 & $-221,198$ & -38.34 & 184,458 & 51.84 \\
\hline \multicolumn{12}{|l|}{ Produktivitas (ku/ha) } \\
\hline 1. Januari-April & 16.00 & 17.18 & 15.76 & 14.49 & 14.46 & -1.42 & -8.27 & -1.27 & -8.06 & -0.03 & -0.21 \\
\hline 2. Mei-Agustus & 14.21 & 14.63 & 13.87 & 14.57 & 14.53 & -0.76 & -5.19 & 0.7 & 5.05 & -0.04 & -0.27 \\
\hline 3. September-Desember & 16.44 & 15.88 & 14.99 & 16.04 & 15.09 & -0.89 & -5.6 & 1.05 & 7 & -0.95 & -5.92 \\
\hline - Januari-Desember & 15.51 & 15.68 & 14.9 & 15.14 & 14.68 & -0.78 & -4.97 & 0.24 & 1.61 & -0.46 & -3.04 \\
\hline \multicolumn{12}{|l|}{ Produksi (ton) } \\
\hline 1. Januari-April & 270,790 & 247,558 & 304,781 & 133,766 & 287,625 & 57,223 & 23 & $-171,015$ & -56.11 & 153,859 & 115.02 \\
\hline 2. Mei-Agustus & 316,281 & 359,133 & 250,623 & 174,906 & 254,233 & $-108,510$ & -30 & $-75,717$ & -30.21 & 79,327 & 45.35 \\
\hline 3. September-Desember & 367,926 & 356,492 & 304,249 & 230,038 & 251,098 & $-52,243$ & -15 & $-74,211$ & -24.39 & 21,060 & 9.16 \\
\hline - Januari-Desember & 954,997 & 963,183 & 859,653 & 538,710 & 792,956 & $-103,530$ & -11 & $-320,943$ & -37.33 & 254,246 & 47.20 \\
\hline
\end{tabular}

Sumber: BPS (2019) 
Berdasarkan Tabel 3, diketahui bahwa luasan lahan panen kedelai cenderung mengalami penurunan jika dibandingkan dengan tahun 2014. Luasan panen kedelai terkecil terjadi pada tahun 2017 yang mencapai 355.789 hektar yang mengalami penurunan sebesar 38,34\% dibandingkan pada tahun 2016. Jika dilihat dari periode musiman, bahwa musim pada periode Januari - April 2017 merupakan penurunan terbesar pada luasan panen kedelai dengan penurunan sebesar 52,27\% dibandingkan pada peiode musim yang sama di tahun 2016. Salah satu faktor yang dapat menyebabkan penurunan ini adalah alih fungsi lahan. Ketidakstabilan harga kedelai membuat petani cenderung beralih menanam jagung atau kacang tanah yang memiliki harga lebih baik dan stabil. Kebijakan impor kedelai juga berpengaruh terhadap preferensi petani. Pasar yang didominasi produsen tahu dan tempe cenderung memilih kedelai impor karena harganya yang lebih murah dengan ukuran yang lebih besar sehingga dinilai lebih cocok digunakan sebagai bahan baku tahu dan tempe. Tidak dapat dipungkiri bahwa sebanyak 50\% kedelai dimanfaatkan untuk produksi menjadi tempe dan 40\% dimanfaatkan untuk produksi tahu, sedangkan 10\% digunakan untuk susu kedelai, kecap, taoge, tauco, tepung, dan produk olahan lainnya (Silitonga dan
Djanuwardi, 1996). Selain itu, kontinuitas kedelai impor yang lebih terjamin, sehingga tidak mengganggu kontinuitas produksi produk olahan kedelai dalam negeri.

Meskipun luasan lahan panen kedelai pada tahun 2017 merupakan luasan yang terkecil, namun produktivitasnya mengalami peningkatan sebesar 1,6\% dibandingkan tahun 2016. Sejalan dengan luasan panen yang mengalami penurunan pada tahun 2017, maka produksi kedelai yang dihasilkan pun juga mengalami penurunan sebesar $37,33 \%$ dengan penurunan terbesar pada musim periode Januari - April 2017.

\section{ANALISIS DAN \\ ALTERNATIF SOLUSI}

Peramalan dapat dijadikan sebagai dasar untuk menentukan target di masa datang yang hendak dicapai oleh seseorang atau organisai. Penentuan target yang tepat harus memenuhi kriteria SMART yakni Specific, Measurable, Achievable, Relevant, dan Time bound. Target yang ditentukan merupakan target yang spesifik, terukur, dapat dicapai, sejalan dengan organisasi dan target lainnya serta memiliki jangka waktu yang jelas. Dengan demikian, target tersebut akan memberikan arahan bagi seseorang atau organisasi dapat berjalan terarah. 
Salah satu jenis peramalan adalah peramalan produksi. Peramalan produksi adalah upaya memperkirakan jumlah produksi yang akan diperoleh di masa yang akan datang dengan menggunakan data historis periode sebelumnya, baik data kuantitatif maupun kualitatif. Peramalan produksi ini memberikan manfaat dalam menentukan alokasi sumber daya yang diperlukan untuk menunjang produksi secara efektif dan efisien dalam pelakanaannnya.

Hasil peramalan produksi kedelai ini akan digunakan sebagai dasar penentuan target produksi yang akan dicapai baik dalam periode tahunan maupun muisman. Tentunya target ini nanti akan dijadiakan sebagai dasar kebijakan dan pernecanaan program kegiatan yang mendorong pengembangan produksi kedelai nasional gubna mengurangi volume kedelai impor.

Peramalan produksi yang dikaji dalam penelitian ini adalah peramalan produksi secara kuantitatif dengan menggunakan data tahunan dan data musiman. Tabel 4 menunjukkan data ramalan produksi tahunan dan tingkat kesalahannya pada periode tahun 20002018. Hasil menunjukkan bahwa metode peramalan kuantitatif yang memiliki nilai MAE, MSE, dan MAPE terkecil adalah metode weighted moving average dengan tingkat eror terkecil $(\mathrm{MAPE}=15,03 \%)$ dengan nilai peramalan $971,489.45$ ton kedelai dan nilai RMSE bernilai 132,732.33 ton. Dengan demikian, target produksi kedelai yang dapat ditentukan adalah berkisar 971,489.45 \pm 132,732.33 ton kedelai.

Untuk data tahunan, metode peramalan yang menggunakan data musiman, diketahui bahwa metode Holt's Winter (Multiplicative) yang memiliki tingkat eror terkecil $(\mathrm{MAPE}=21,98 \%)$. Hasil peramalan untuk periode Januari-April 61,133.67 $\pm 205,386.97$ ton; Mei-Agustus 61,133.67 $\pm 240,794.38$ ton; dan September-Desember $\quad 61,133.67 \quad \pm$ 281,164.55 ton. Dengan demikian, target musiman yang bisa digunakan sebagai dasar untuk membuat target produksi kedelai oleh Kementarian Pertanian dapat berkisar di rentang nilai peramalan tersebut. Dengan demikian, kedua metode tersebut dapat diadopsi oleh Kementerian Pertanian dalam menentukan target produksi kedelai untuk produksi tahunan dan produksi musiman. 
Tabel 4 Proyeksi peramalan dan penentuan target produksi kedelai tahun 2019

\begin{tabular}{|c|c|c|c|c|c|c|c|}
\hline Metode Peramalan & Periode & RMSE & Peramalan (ton) & MAE & MSE & MAPE & Target (ton) \\
\hline Moving Average & 2019 & $161,616.28$ & $793,659.67$ & $130,322.85$ & $26,119,820,948.95$ & $17.40 \%$ & $793,659.67 \pm 161,616.28$ \\
\hline $\begin{array}{l}\text { Weighted Moving } \\
\text { Average }\end{array}$ & 2019 & $132,732.33$ & $971,489.45$ & $115,047.17$ & $17,617,870,401.31$ & $15.03 \%$ & $971,489.45 \pm 132,732.33$ \\
\hline Exponential Smoothing & 2019 & $161,814.32$ & $846,836.16$ & $131,994.29$ & $26,183,875,559.51$ & $17.71 \%$ & $846,836.16 \pm 161,814.32$ \\
\hline Holt's Trend & 2019 & $161,814.32$ & $846,836.16$ & $131,994.29$ & $26,183,875,559.51$ & $17.71 \%$ & $846,836.16 \pm 161,814.32$ \\
\hline \multirow{4}{*}{$\begin{array}{l}\text { Holt's Winter } \\
\text { (Mult) }\end{array}$} & 2019 & & & & & & \\
\hline & - Januari-April & $61,133.67$ & $205,386.97$ & $50,245.26$ & $3,737,325,525.76$ & $21.98 \%$ & $205,386.97 \pm 61133.67$ \\
\hline & - Mei-Agustus & $61,133.67$ & $240,794.38$ & $50,245.26$ & $3,737,325,525.76$ & $21.98 \%$ & $240,794.38 \pm 61,133.67$ \\
\hline & - September-Desember & $61,133.67$ & $281,164.55$ & $50,245.26$ & $3,737,325,525.76$ & $21.98 \%$ & $281,164.55 \pm 61,133.67$ \\
\hline \multirow[t]{4}{*}{ Holt's Winter (Addt) } & 2019 & & & & & & \\
\hline & - Januari-April & $64,806.64$ & $184,926.82$ & $53,814.32$ & $4,199,900,041.20$ & $23.22 \%$ & $184,926.38 \pm 64,806.64$ \\
\hline & - Mei-Agustus & $64,806.64$ & $231,327.37$ & $53,814.32$ & $4,199,900,041.20$ & $23.22 \%$ & $231,327.37 \pm 64,806.64$ \\
\hline & - September-Desember & $64,806.64$ & $283,881.93$ & $53,814.32$ & $4,199,900,041.20$ & $23.22 \%$ & $283,881.93 \pm 64,806.64$ \\
\hline
\end{tabular}




\section{DAFTAR PUSTAKA}

Aldilah, R. 2015. Proyeksi Produksi dan Konsumsi Kedelai Indonesia. Jurnal Ekonomi Kuantitatif Terapan (8/1) Februari 2015: pp 9-23.

BPOM (Badan Pengawas Obat dan Makanan Republik Indonesia). 2005. Peraturan Kepala Badan Pengawas Obat dan Makanan Republik Indonesia tentang Ketentuan Pokok Pengawasan Pangan Fungsional. Jakarta.

BPS (Badan Pusat Statistik). 2019. Produksi Kedelai. Tersedia pada: www.bps.go.id. (19 September 2019).

Departemen Pertanian. 2008. Mutu Kedelai Nasional Lebih Baik dari Kedelai Impor[Siaran Pers]. Jakarta: Badan Litbang Pertanian. http://pustaka.litbang.deptan.go.id
/ bppi/lengkap/sp1202081.pdf [25 Oktober 2019].

FAO. 2013. FAOSTAT Database. http://faostat.fao.org/ site/339/default.aspx. [25 Oktober 2019].

Krisnawati, A. 2017. Kedelai Seabagai Sumber Pangan Fungsional. Iptek Tanaman Pangan (12/1) 2017: pp 57-65.

Malian, A. Husni. 2004. Kebijakan Perdagangan Internasional Komoditas Pertanian di Indonesia. Analisis Kebijakan Perdagangan (2/2) Juni 2004. Bogor: Pusat Analisis Sosial Ekonomi dan Kebijakan Pertanian.

Silitonga, C., Djanuwardi. B. 1996. Konsumsi Tempe. hlm. 209-229. Dalam: Sapuan dan Noer Sutrisno (Ed.). Bunga Rampai Tempe Indonesia. Yayasan Tempe Indonesia, Jakarta. 